\title{
Genetic differentiation of the Iceland scallop Chlamys islandica (Pectinidae) in the northern Atlantic Ocean
}

\author{
Svein Erik Fevolden \\ Department of Marine Zoology and Marine Chemistry, University of Oslo, PO Box 1064, Blindern, N-0316 Oslo 3, Norway
}

\begin{abstract}
Allozymic variation at gene loci encoding for glucosephosphate isomerase, phosphoglucomutase and superoxide dismutase was investigated in populations of Chlamys islandica from waters around Jan Mayen, Spitsbergen, Bear Island and northern Norway. The Gpi locus was particularly polymorphic with at least 12 different alleles and a mean heterozygosity of $84 \%$ Half the individuals were heterozygous at Pgm-2 and between 30 and $40 \%$ at Sod. The high polymorphism at Gpi runs counter to an earlier hypothesis suggesting a positive correlation between environmental variability and Gpi polymorphism of pectinids. Pgm-2 and Sod revealed significant allele frequency heterogeneity among the different areas, Gpi only when the effective number of alleles was considered. The species has a large dispersal potential during a long planktonic larval stage, but information on the surface current system in the North Atlantic suggests that restricted gene flow, with possible contributions from selective constraints, account for the observed pattern in gene variability. It is suggested that the conservative approach of managing each area as if it contained discrete genetic units of the species should be adopted.
\end{abstract}

\section{INTRODUCTION}

The Iceland scallop Chlamys islandica (O. F. Müller) is an arctic/boreal bivalve with a circumpolar distribution. It is the most abundant species of scallop in Atlantic sub-Arctic and Arctic regions (Ekman 1953, Wiborg 1963, Luka et al. 1987). The scallop lives in cold water from below zero to between 8 and $10^{\circ} \mathrm{C}$ on gravel or sandy bottoms at depths from 20 to $100 \mathrm{~m}$ (Ekman 1953, Wiborg 1963).

Since the mid-seventies, various pectinids have been studied for protein polymorphism using electrophoretic techniques (Wilkins \& Mathers 1974, Mathers 1975, Wilkins 1975, 1978, Beaumont et al. 1980, Beaumont 1982a, b, Fujio et al. 1983, Beaumont \& Beveridge 1984, Foltz \& Zouros 1984, Macleod et al. 1985, Gosling \& Burnell 1988). Biochemical genetic data has successfully been used to investigate the genetic population structure of pectinids (Beaumont 1982a, Macleod et al. 1985). Beaumont (1982a) investigated Chlamys opercularis, which has a more southerly distribution than $C$. islandica, and found genetically isolated populations around the British Isles despite a potentially large dispersal capacity through planktonic larvae. He argued that both random genetic drift and selection may be involved in the establishment and retention of large allele frequency differences between isolated populations.

In the absence of natural selection and genetic drift, gene flow through larval dispersal in marine invertebrates might be expected to generate uniform allele frequencies among conspecific populations over the dispersal area (see e.g. Gooch 1975, Scheltema 1975, Crisp 1978). However, Burton (1983) claimed that there is no strong support for a relationship between the length of the planktonic larval stage and the geographic boundaries of panmictic populations. Substantial population differentiation has been observed despite a high dispersal capacity, a situation which may partly be caused by natural selection, or physical barriers to dispersal (Burton 1983, see also Hedgecock 1986). As a spatially widespread organism with a longlasting planktonic larval stage (up to $2 \mathrm{mo}$ ) Chlamys islandica was considered a suitable organism in which to study the effects of larval dispersal on genetic population structure.

Intensive exploitation of Iceland scallop started in Norway only 4 yr ago (in 1985). Fishing began on the 
scallop beds around Jan Mayen, which are already being heavily depleted, and later shifted to areas around Bear Island and off West Spitsbergen where the densest concentrations of commercial size are found (Rubach \& Sundet 1987). For management purposes it is therefore important to determine the genetic structure of the species.

If the coastal current system in the northern Atlantic is considered, it is obvious that larval dispersal may be extensive. If larval behaviour does not result in the retention of self-sustaining stocks, it is quite possible that larvae spawned in one area are transported to and settle in regions far away from their origin. With this point in mind scallops were sampled from all major commercial scallop fishing grounds for Norwegian fishermen to elucidate the degree of differentiation in the population structure of the species.

High polymorphism has generally been reported in pectinids for the gene coding for glucosephosphate isomerase (references listed above). Early on, it was suggested that this locus is more polymorphic in species which experience high environmental variability (Mathers 1975, Wilkins 1975). During the course of this study, high variability at Gpi was also revealed in Chlamys islandica. Since the Iceland scallop is an inhabitant of what may appear to be an extremely stable environment (deep sublittoral habitats in cold regions), its allozymic variability will therefore be discussed in relation to the genetics of pectinids living in more temperate regions.

\section{MATERIAL AND METHODS}

The scallops were dredged from RV 'Johan Ruud' during summer 1987, except for the Thomso sample which was taken in November 1986. Samples for electrophoresis were randomly collected from the dredges to ensure a non-biased size or age distribution. The 8 sample sites are shown in Fig. 1 and other details given in Table 1.

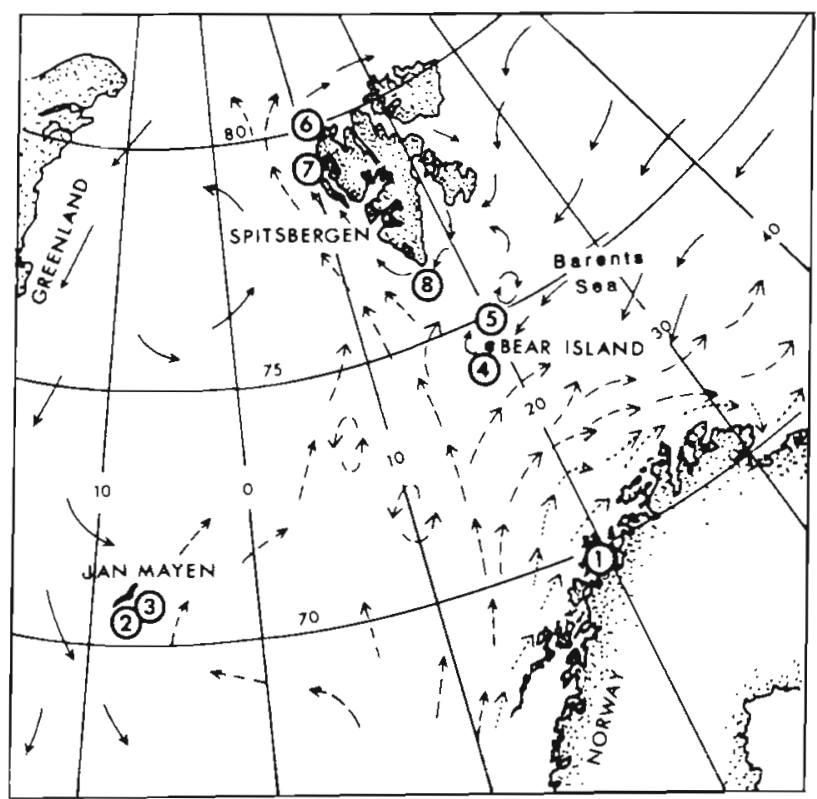

Flg. 1. Sampling sites of Chlamys islandica. Arrows indicate surface currents in the North Atlantic. -.-> = Atlantic currents, $\longrightarrow=$ polar currents, $\cdots>=$ Norwegian Coastal Current

The adductor muscles and gonads were dissected out from fresh specimens and immediately frozen at $-80^{\circ} \mathrm{C}$. Before electrophoresis approximately equal amounts of muscle and gonad were homogenized in a solution containing $100 \mu \mathrm{l}$ Triton X-100, $100 \mu \mathrm{l} \beta$-mercaptoethanol, and $10 \mathrm{mg}$ NADP per $100 \mathrm{ml}$ distilled water The homgenates were centrifuged at $12000 \mathrm{~g}$ for 15 min and supernatants were saved for electrophoresis. Altogether nearly 1700 scallops were analysed using starch gel electrophoresis (as in Ayala et al. 1973).

The reaction of 28 different enzyme stains plus one general protein stain was initially tested, but only the 3 most polymorphic systems will be dealt with in detail here. They are: glucosephosphate isomerase (GPI, E.C. 5.3.1.9), phosphoglucomutase (PGM, E.C. 2.7.5.1), and

Table 1. Chlamys islandica. Sampling stations with depth of highest shell concentration and approximate temperature during the summer season (Sundet pers. comm.)

\begin{tabular}{|lcr|}
\hline Locality & Depth of maximum concentrations $(\mathrm{m})$ & Temperature $\left({ }^{\circ} \mathrm{C}\right)$ \\
\hline 1 Tromsø, Berg & $30-50$ & $2-6$ \\
2. Jan Mayen, Straumflaket & $70-100$ & $0.5-1.2$ \\
3. Jan Mayen, north of Straumflaket & $70-100$ & $0.5-1.2$ \\
4. Bear Island South & $70-110$ & ca 2.3 \\
5. Bear Island North, Kvertehola & $70-110$ & ca 2.3 \\
6. Spitsbergen, Breibogen & $40-70$ & $3.8-4.8$ \\
7 Spitsbergen, Sjubreflaket & $30-100$ & $3.4-5.8$ \\
8. Spitsbergen, Sorkapp & $60-100$ & ca 1 \\
\hline
\end{tabular}


superoxide dismutase (SOD, E.C. 1.15.1.1). The staining of GPI and PGM followed Fevolden \& Ayala (1981) with modifications as in Haug \& Fevolden (1986). SOD bands were visualized in a solution containing $5 \mathrm{mg}$ riboflavin, $75 \mathrm{mg}$ EDTA, and $10 \mathrm{mg} \mathrm{NBT}$ (nitroblue tetrazolium) in $100 \mathrm{ml}$ of $0.05 \mathrm{M}$ Tris- $\mathrm{HCl} \mathrm{pH} 8.0$. After incubation in the dark for 20 min gels were exposed to strong light leaving oxidase activity as white bands. Staining of the remaining systems (listed under 'Results') followed Fevolden \& Ayala (1981).

The Tris-citric acid ( $\mathrm{pH} 8.5$; gel) and lithium hydroxide boric acid ( $\mathrm{pH}$ 8.1; electrode) butter system of Ridgway et al. (1970) gave best resolution of the GPI and SOD bands and also good resolution for the faster of 2 polymorphic PGM bands. PGM was also analysed in the following system: gel buffer $5.9 \mathrm{mM}$ $\mathrm{K}_{2} \mathrm{HPO}_{4} \cdot 3 \mathrm{H}_{2} \mathrm{O}, 1.2 \mathrm{mM}$ citric acid, $\mathrm{pH} 7.0$; bridge butter $160.7 \mathrm{mM} \mathrm{K} \mathrm{K}_{2} \mathrm{PO}_{4} \cdot 3 \mathrm{H}_{2} \mathrm{O}, 27.1 \mathrm{mM}$ citric acid, $\mathrm{pH} 6.7$ (modified after Selander \& Yang 1969). This system yielded wider separation of the different allelic bands in the faster Pgm locus, and also showed activity in the slower Pgm locus. The latter locus is highly polymorphic, but uneven migration makes interpretation difficult

The different alleles are assigned figures where 100 designates the commonest allele. The designation of the remaining alleles indicates their percentage mobility relative to the 100 allele. Since there was a large number of alleles at the Gpi locus, the effective number of alleles was calculated using the formula $n_{e}=1 / \Sigma p_{i}^{2}$ where $p_{1}$ is the frequency of the ith allele.

Conformity to Hardy-Weinberg expectations of genotype distribution in a random mating population was tested by calculating Wright's $F_{\text {IS }}$ value (fixation index of subpopulations; Wright 1965). Positive and negative values of $F_{\mathrm{IS}}$ indicate excess and deficit of homozygotes. The significance of $F_{\text {IS }}$ was tested by calculating $\chi^{2}$ as $F_{15}{ }^{2} N$, where $N$ is sample size (Li 1955, Brown 1970). Inter-sample heterogeneity in allele frequencies was tested by contingency table analyses. To reveal similarities between samples cluster analysis was performed on matrices of Nei's (1972) genetic distances using unweighted pair group method with arithmetic averages.

\section{RESULTS}

Loci coding for 11 proteins were monomorphic (aldolase, esterase-1, fumarase, hexokinase-1, isocitrate dehydrogenase, malic enzyme, 6-phosphogluconate dehydrogenase, xanthine dehydrogenase, plus 3 unidentified protein loci). For cost-efficiency reasons and because they were considered less likely to provide information on stock structuring, these loci were examined only for the Tromsø sample. Nine enzyme stains produced variable gel bands that could not be consistently scored (adenyl kinase, esterase, glucose-6phosphate dehydrogenase, glyceraldehyde-3-phosphate, $\alpha$-glycerophosphate dehydrogenase, hydroxybutyrate dehydrogenase, mannosephosphate isomerase, octanol dehydrogenase, and sorbitoldehydrogenase). Enzyme stains for 8 systems produced no visible, or very weak bands (acid phosphatase, alkaline phosphatase, aldehyde oxidase, aspartate aminotransferase, glucose dehydrogenase, lactate dehydrogenase, leucine aminopeptidase and malate dehydrogenase).

Only 3 of the polymorphic enzyme systems showed consistent gel resolution. The dimeric GPI was the most variable. This enzyme is encoded at a single locus and at least 12 different alleles were observed. Seven samples contained no less than 10 alleles; 9 alleles were observed in the Tromsø locality alone (Table 2). Additional low-frequency alleles had positions so close to other alleles that they could not be scored with certainty. They were therefore pooled with their neighbouring alleles. The effective number of alleles, which takes into account the reduced contribution to variability by low-frequency alleles, varied between 4.79 and 5.97 (Table 2). As a result of the high number of codominant alleles as many as 50 different genotypes were actually scored. More than $80 \%$ of the individuals in any one sample were heterozygous at this locus (Table 2).

The monomeric enzyme PGM is encoded at 2 loci. Pgm-2 showed 5 alleles, 2 of which were rare (Table 3 ). Half the individuals were heterozygous for this locus. The slower migrating bands representing Pgm-1 were also highly polymorphic ( $\geq 4$ alleles), but the locus could not be scored with confidence

The dimeric SOD is also encoded at a locus with 5 different alleles of which 2 were rare (Table 4). Between 28 and $43 \%$ of the individuals in any one sample were heterozygous at this locus.

Average heterozygosity over the 3 polymorphic loci plus the 11 monomorphic was estimated at 0.116 (Tromsø sample).

Wright's fixation index revealed a general conformity to Hardy-Weinberg expectations with the few significant exceptions shown in Tables 2 to 4 . For Gpi, significant $F_{\text {IS }}$ values in populations 3 and 5 were caused by deficits of homozygotes of specific alleles. The mean of $F_{I S}$, however, is negative in 7 of 8 samples of Gpi and 6 of 8 samples of Sod (Tables 2 and 4), indicating a slight, but general excess of heterozygotes. At $P g m-2$, significant $F_{\mathrm{IS}}$ values in populations 2 and 6 were caused by a surplus of homozygotes. In population 2, however, the significance was due to the observation of one rare homozygote with a low expected value $(0.011)$ and this result is presumably not biologi- 


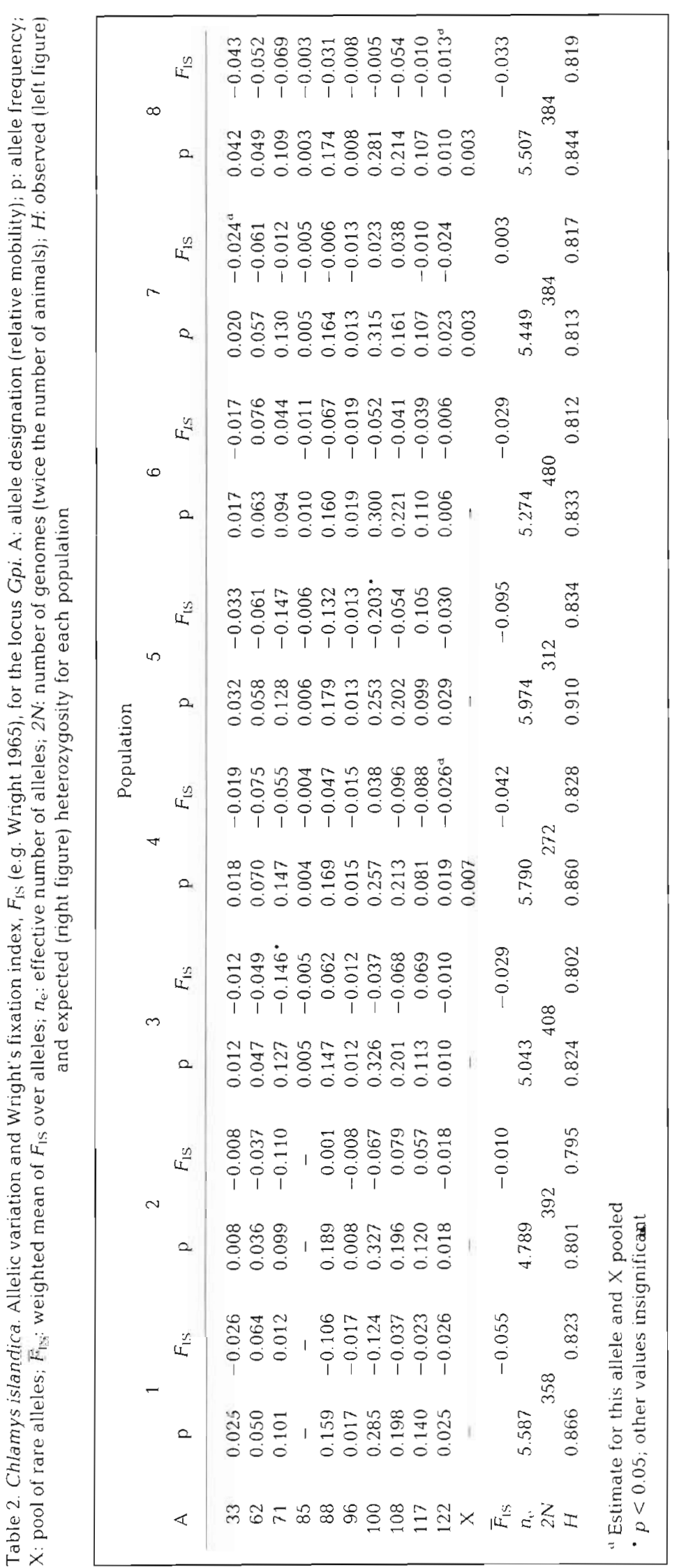



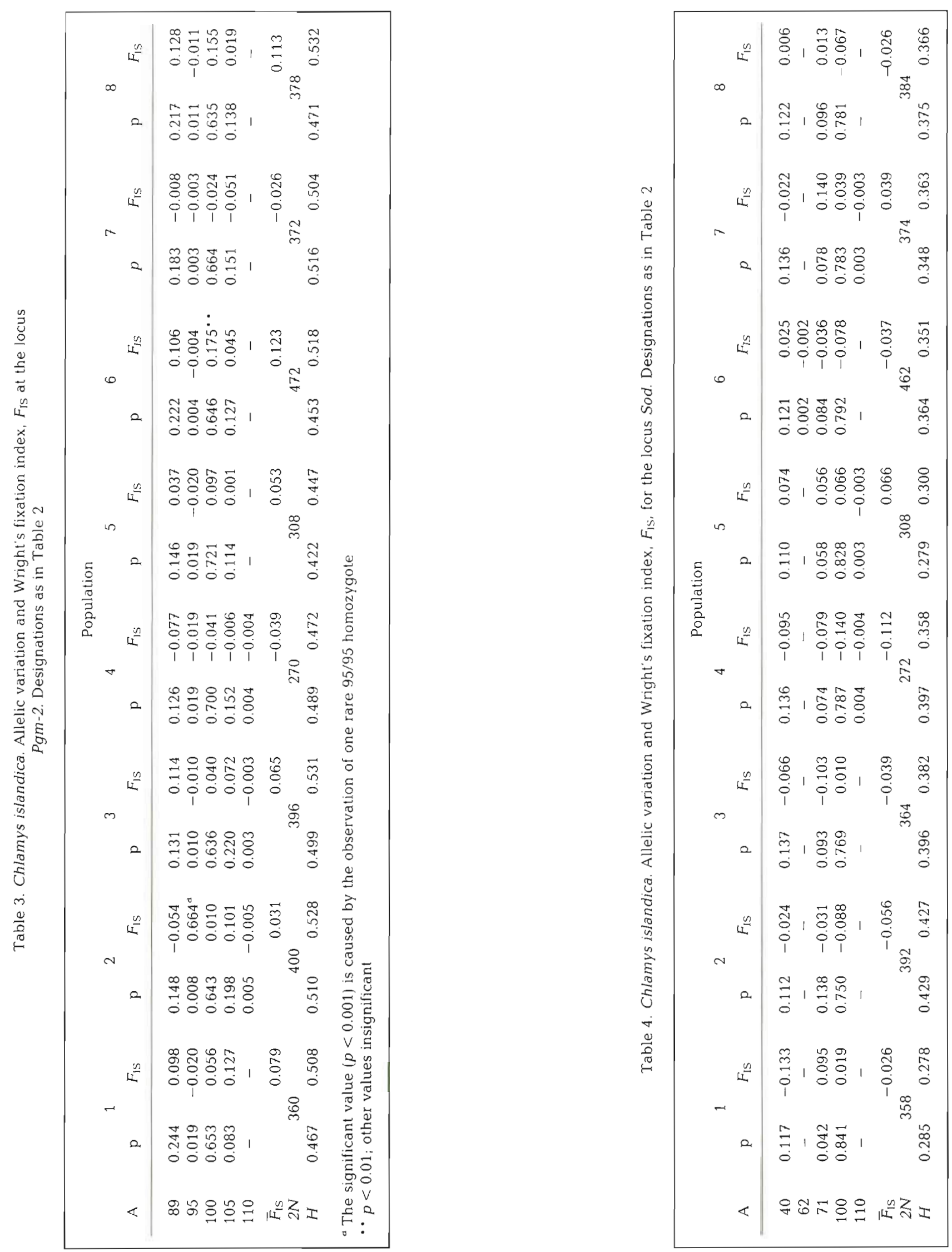
Table 5. Chlamys islandica. Contingency chi-square analysis of inter-sample and inter-area heterogeneity at the 3 polymorphic loci. Alleles with expected values less than 1 are pooled with alleles having the next highest value

\begin{tabular}{|lcccrrr}
\hline Locus & & Inter-sample & & \multicolumn{2}{c}{ Inter-area } \\
& Chi-square & $\mathrm{df}$ & $p$ & Chi-square & $\mathrm{df}$ & $p$ \\
\hline Gpi & 69.108 & 63 & 0.279 & 36.346 & 27 & 0.112 \\
Pgm-2 & 78.142 & 21 & $<0.001$ & 71.130 & 9 & $<0.001$ \\
Sod & 28.734 & 14 & $<0.02$ & 20.829 & 6 & $<0.005$ \\
Additive & 175.984 & 98 & $<0.001$ & 128305 & 42 & $<0.001$ \\
\hline
\end{tabular}

cally significant. Nevertheless, the mean of $F_{\mathrm{IS}}$ over alleles at $\mathrm{Pgm}-2$ in 6 of 8 populations is positive (Table $3)$, as is the mean of $F_{\text {IS }}$ over populations (0.051), indicating a small overall escess of homozygotes.

Contingency table analyses revealed no inter-sample heterogeneity at the highly polymorphic Gpi locus, but significant heterogeneity both at $\mathrm{Pgm}-2$ and Sod (Table 5). No significant heterogeneity was found among samples within any of the different regions $(p \geqslant 0.12)$. Pooling samples within each geographical region - Jan Mayen, Spitsbergen, Bear Island, Tromsø (only one sample) - revealed highly significant inter-region heterogeneity at Pgm-2 and Sod (Table 5). No interregion heterogeneity was seen at Gpi using normal procedures for pooling classes with low expectations. However, the exceptionally high number of alleles at Gpi produces high degrees of freedom. When only 6 allele classes were used - the 5 most frequent (according to the calculated effective number of alleles) plus a pool of the remaining alleles - a slightly significant inter-area heterogeneity is seen even at this locus $\left(\chi_{15}{ }^{2}\right.$ $=26.757 ; 0.05>p>0.025$ )

The dendrogram based on Nei's (1972) genetic distance averaged across the 3 polymorphic loci (Fig. 2) shows that populations sampled within each of the different areas are clustered together, leaving the Jan Mayen samples as genetically most distant from any other sample.

\section{DISCUSSION}

\section{Intra-sample allozyme variation}

The 3 polymorphic loci all show high intra-sample variability. Although the different alleles have not been confirmed by breeding trials, the consistency in banding patterns with characteristics as expected for monoand dimeric enzymes, and general conformity to Hardy-Weinberg expectations, suggest that the isozyme variants are genetically based and inherited in simple Mendelian fashion.

High variability at Gpi in terms of number of alleles and heterozygosity has also been found in other and more southerly distributed pectinids (Wilkins \& Mathers
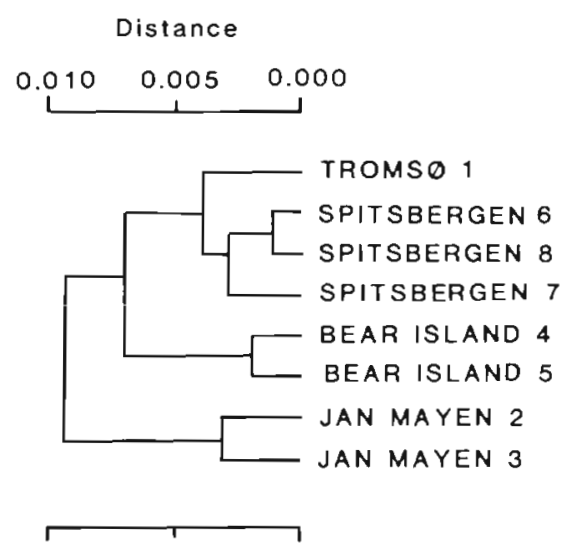

Fig. 2. Chlanys islandica. Cluster dendrogram based on Nei's (1972) genetic distance for pairwise comparison of samples across the three polymorphic loci Gpi, Pgm-2, and Sod. Unweighted pair-group method with arịthmetic averaging has been used to construct the dendrogram

1974, Mathers 1975, Wilkins 1975, 1978), although only in Pecten maximus of the same magnitude as in Chlamys islandica (Wilkins \& Mathers 1974, Wilkins 1978, Beaumont \& Beveridge 1984). Beaumont \& Beveridge (1984) measured a Pgm heterozygosity in Chlamys opercularis similar to that reported here for $C$. islandica, even higher values for $C$. distorta, but significantly lower values for $C$. varia and Pecten maximus. All 4 species were sampled in the Irish Sea. SOD has been much less studied in bivalves than GPI and PGM, but there appears to be generally lower polymorphism at this locus than found here for C. islandica. Beaumont \& Beveridge (1984) found Sod to be monomorphic in $C$. varia and $C$. distorta, and to show inconsistent resolution in $C$. opercularis and $P$. maximus, although with unquantified variability in the latter

There has been a great deal of speculation about the ecological/biological significance of differentiated gene variation among marine organisms, that is whether or not there is an adaptive strategy to the variation. Despite difficulties in classifying the interactions between the environment and the species and the different species' perception of the environment (see Nelson \& Hedgecock 1980, Nevo et al. 1984), substantial contributions to the neutral-selection controversy are still 
frequently published (e.g. Mitton \& Grant 1984, Nevo et al. 1984, Hedrick 1986, Koehn \& Hilbish 1987, Lavie et al. 1987, Noy et al. 1987).

At an early stage, it was postulated that bivalves which experience greater environmental variability are more polymorphic, particularly at Gpi, than those living in more constant environments (Levinton 1973, Mathers 1975, Wilkins 1975); polymorphism should enhance fitness in variable environments (in accordance with the niche-width hypothesis; van Valen 1965). On comparing the inter-tidal Chlamys varia with the sub-littoral $C$. opercularis, it was concluded that at least as long as species within the same genus are compared, a more stable environment (sublittoral) is typical for more monomorphic species (Mathers 1975). The high variability observed in the relatively deep living Pecten maximus did not fit this model, but could be related to the species' ability to swim, resulting in opportunities for experiencing a more variable environment (Wilkins 1975). Both C. opercularis and C. islandica swim, live on similar substrates, and at similar depths, but $C$. islandica lives in much colder water - presumably in a more stable environment, or a narrower niche. It is interesting, therefore, to observe that $C$. islandica shows significantly higher Gpi polymorphism than C. opercularis, in fact the highest found in any member of the genus Chlamys. Also the variability at $P g m$ and Sod in C. islandica is equal to or greater than that of pectinids from environments which are presumably spatiotemporally more heterogeneous.

Yet, the whole enigma again ends up with speculations about how the Iceland scallop actually perceives its environment, and whether its niche is in fact narrow or wide compared to those of the more temperate species. Although the arctic/subarctic environment of Chlamys islandica is stable in theory with, for instance, only minor temporal and spatial variation in temperature, other factors like food supply vary during the year. Moreover, by videomonitoring the species habitat we have seen (unpubl.) that it seems so thrive on a wide variety of substrates, from crevices between large rocks to flat, sandy, and occasionally almost muddy bottom. Considering also its wide geographical distribution, it could thus be argued that the scallop's niche is in fact wide. This argumentation illustrates one problem of relating specific gene variability to a species' fitness. Rating environments according to heterogeneity is still a very subjective process.

\section{Inter-sample variation, gene flow and population} structuring

The variability at both Pgm and Sod was significantly heterogeneous over the sampling area, whilst the highly polymorphic Gpi locus showed significant inter- area heterogeneity only when the effective number of alleles was considered. The pattern of variation was such that each geographical area formed a cluster. Due to the large population sizes, and the long life span of the species ( $\geq 20 \mathrm{yr}$ ), which meant that many age cohorts were sampled, random genetic drift is not considered likely to account for the inter-area differentiation. Other models, selective and neutral, can better explain this observation, e.g.: (1) The long larval stage of Chlamys islandica has a potential for extensive gene flow and panmixia, but local adaptive selection may act on the settling larvae causing inter-area gene diversity among the adult populations; (2) the differentiated allele frequency variability is a result of reduced gene flow and the existence of more or less reproductively isolated stocks.

If environmental selection acts upon the settling larvae (or upon spat after settling) one might expect the adult population to be in Hardy-Weinberg disequilibrium. The surplus of homozygotes frequently seen at the Pgm locus could of course theoretically indicate that homozygotes are fitter than the corresponding heterozygotes, but alternative explanations like mixing of different genetic units (Wahlund effect) must also be considered (unless all the immigrant larvae are selected against before maturation). Such a surplus of homozygotes seems to be a common feature among marine bivalves (Fujio et al. 1983, Beaumont \& Beveridge 1984, Foltz \& Zouros 1984, Zouros \& Foltz 1984), although no unambiguous explanation for the phenomenon has been found. Moreover, the pattern of variability for Gpi and Sod revealed frequent excesses of heterozygotes, opposite to that of $\mathrm{Pgm}$ and indicative of heterosis. Thus, the possibility that some of the diversity observed among the geographic regions is retained by natural selection cannot be discounted - a selection which of course could act upon loci linked to those studied.

On the other hand, considering the rather complex current system in the northern Atlantic, it is quite possible that the gene diversity is mainly of a neutral pattern, i.e. physical factors restrict larval dispersal and gene flow between areas. The behaviour of Iceland scallop larvae is to a large extent unknown, but presumably they are dispersed through the upper part of the water column where they will be subject to transport with the surface water currents. Dispersal of larvae with surface currents from N Norway to Bear Island, and as far north as Spitsbergen, is only possible if larvae spawned along the coast of N Norway reach the Norwegian Atlantic Current outside the Norwegian Coastal Current (Fig. 1). The latter, however, is likely to transport larvae into the eastern Barents Sea, which may in fact be the normal regime. If the larvae did reach the Atlantic current, they are likely to pass Bear 
Island too far off the west coast to settle in the scallop beds there. Moreover, the local current system around Bear Island is very complex. A surface gyre NE of the island, and certainly within reach of locally spawned larvae, could restrict larval dispersal, and possibly engender a self-sustaining stock. The scallops growing off the coast of Spitsbergen, on the other hand, seem to be dependent on an influx of larvae since locally spawned larvae are likely to drift north and out of the region. However, scallops from the coast of Norway do not seem a very likely source. There is no reason to believe that there is extensive gene exchange between Jan Mayen and the remaining areas since there are prevailing northerly currents both east of Jan Mayen and west of Norway/Bear Island/Spitsbergen. Physical barriers could thus account for the distinct difference in allozyme variability between Jan Mayen and the remaining areas.

The information now available on Chlamys islandica is in itself insufficient to discriminate between diversifying selective constraints and restricted gene flow, although one must assume that neutral factors contribute significantly to the gene diversity that has been observed. Gene flow can of course be stepwise and a gross circulatory pattern may exist that over generational time ties some of the different geographical populations in the North Atlantic together; however, this gene flow is apparently insufficient to create a genetically homogeneous stock. For management purposes, therefore, the data suggest that the conservative approach of considering each area as if it was inhabited by semi-discrete genetic units, which should be managed independently of one another, should be adopted.

Acknowledgements. Thanks are due to the crew on board RV 'Johan Ruud' for assistance in sampling shells. Financial support was granted by the Norwegian Fishery Research Council.

\section{LITERATURE CITED}

Ayala, F. J., Hedgecock, D., Zumwalt, G. S., Valentine, J. W (1973). Genetic variation in Tridacna maxima, an ecological analog of some unsuccessful evolutionary lineages. Evolution 27: 177-191

Beaumont, A. R. (1982a). Geographic variation in allele frequencies at three loci in Chlamys opercularis from Norway to the Brittany coast. J. mar. biol. Ass. U. K. 62: 243-261

Beaumont, A. R. (1982b). Variation in heterozygosity at two loci between year classes of populations of Chlamys opercularis (L.) from a Scottish sea loch. Mar. Biol. Lett. 3: 25-34

Beaumont, A. R., Beveridge, C. M. (1984), Electrophoretic survey of genetic variation in Pecten maximus, Chlamys opercularis, $C$. varia, and $C$. distorta from the Irish Sea. Mar. Biol. 81: 299-306

Beaumont, A. R., Day, T R., Gäde, G. (1980). Genetic variation in the octopine dehydrogenase locus in the adductor muscle of Cerestoderma edule (L.) and six other bivalve species. Mar. Biol. Lett. 1: 137-148

Brown, A. H. D. (1970). The estimation of Wright's fixation index from genotypic frequencies. Genetica 41: 399-406

Burton, R. S. (1983). Protein polymorphism and genetic differentiation of marine invertebrate populations. Mar. Biol. Lett. 4: 193-206

Crisp, J. D. (1978). Genetic consequences of different repro ductive strategies in marine invertebrates. In: B. Battaglia, Beardmore, J. A. (eds.) Marine organisms: genetics, ecology, and evolution. Plenum Press, New York, p. 257-273

Ekman, S. (1953). Zoogeography of the sea. Sidgwick and Jackson, London

Fevolden, S. E., Ayala, F. J. (1981). Enzyme polymorphism in Antarctic krill (Euphausiacea); genetic variation between populations and species. Sarsia 66: 167-181

Foltz, D. W., Zouros, E. (1984). Enzyme heterozygosity in the scallop Placopecten magellanicus (Gmelin) in relation to age and size. Mar. Biol. Lett. 5: 255-263

Fujio, Y., Yamanaka, R., Smith, P. J. (1983). Genetic variation in marine molluscs. Bull. Jap. Soc. Sci. Fish. 49: 1809-1817

Gooch, J. L. (1975). Mechanisms of evolution and population genetics. In: Kinne, O. (ed.) Marine ecology, Vol. II, Part 1. Wiley \& Sons, London, p. 349-409

Gosling, E. M., Burnell, G. M. (1988). Evidence for selective mortality in Chlamys varia (L.) transplant experiments. J. mar. biol. Ass. U. K. 68: 251-258

Haug, T., Fevolden, S. E. (1986). Morphological and biochemical genetics of Atlantic halibut, Hippoglossus hippoglossus (L.) from various spawning grounds. J. Fish Biol. 88: $367-378$

Hedgecock, D. (1986). Is gene flow from pelagic larval dispersal important in the adaptation and evolution of marine invertebrates? Bull. mar Sci. 39: 550-564

Hedrick, P. W. (1986). Genetic polymorphism in heterogeneous environments: a decade later. Ann. Rev. Ecol. Syst. 17: 535-566

Koehn, R. K., Hilbish, T. J. (1987). The adaptive importance of genetic variation. Am. Sci. 75: 134-141

Lavie, B., Noy, R., Nevo, E. (1987). Genetic variability in the marine gastropods Patella coerulea and Patella aspera: patterns and problems. Mar. Biol. 96: 367-370

Levinton, J. (1973). Genetic variation in a gradient of environmental variability. Science 180: 75-76

Li, C. C. (1955). Population genetics. University of Chicago Press

Luka, G. I., Mukhin, A. l., Ponomarenko, V P. (1987). Living resources of the Arctic and Sub-Arctic regions and their exploitation. Coun. Meet int. Coun. Explor. Sea C. M. ICES/D, p. $1-32$

Macleod, J. A. A., Thorpe, J. P., Duggan, N. A. (1985). A biochemical genetic study of population structure in queen scallop (Chlamys opercularis) stocks in the Northern Irish Sea. Mar. Biol. 87: 77-82

Mathers, N. F. (1975). Environmental variability at the phosphoglucose isomerase locus in the genus Chlamys. Biochem. Syst. Ecol. 3: 123-127

Mitton, J. B., Grant, M. C. (1984). Associations among protein heterozygosity, growth rate, and developmental homeostasis. Ann. Rev. Ecol. Syst. 15: 4.79-499

Nei, M. (1972). Genetic distance between populations. Am. Nat. 106: 283-292

Nelson, K., Hedgecock, D. (1980). Enzyme polymorphism and adaptive strategy in the decapod Crustacea. Am. Nat. 116: $238-280$

Nevo, E., Beiles, A., Ben-Shlomo, R. (1984). The evolutionary 
significance of genetic diversity: ecological, demographic and life history correlates. In: Mani, G. S. (ed.) Evolutionary dynamics of genetic diversity. Lect. Notes Biomathem. 53: 13-213

Noy, R., Lavie, B., Nevo, E. (1987). The niche-width varation hypothesis revisited: genetic diversity in the marine gastropods Littorina punctata (Gmelin) and L. neritoides (L.) J. exp. mar. Biol. Ecol. 109: 109-116

Ridgway, G. J., Sherbourne, S. W., Lewis, R. D. (1970). Polymorphism in the esterases of the Atlantic herring. Trans Am. Fish. Soc. 99: 147-151

Rubach, S., Sundet, J. H. (1987). Ressurskartlegging av haneskjell (Chlamys islandica O. F. Müller) ved Jan Mayen og i Svalbardsonen i 1986. Rep. University of Tromsø

Scheltema, R. S. (1975). Relationship of larval dispersal, geneflow and natural selection to geographic variation of benthic invertebrates in estuaries and along coastal regions. In: Cronin, L. E. (ed.) Estuarine research, Vol. 1, Chemistry, biology and the estuarine system. Academic Press, New York, p. 372-391

Selander, R. K., Yang, S. A. (1969). Protein polymorphism and genic heterozygosity in a wild population of the house mouse (Mus musculus). Genetics 63: 653-667

Zouros, E., Foltz, D. W (1984). Possible explanations of heterozygote deficiency in bivalve molluscs. Malacologia 25: $583-591$

van Valen, L. (1965). Morphological variation and width of ecological niche. Am. Nat. 99: 377-390

Wiborg, K. (1963). Some observations on the Iceland scallop (Chlamys islandica) (Müller) in Norwegian waters. Fisk. Dir Skr Ser Havunders. 13: 38-53

Wilkins, N. P. (1975). Phosphoglucose isomerase in marine molluscs. In: Markert, C. L. (ed.) Isozymes, IV Genetics and evolution. Academic Press, New York, p. 931-943

Wilkins, N. P. (1978). Length correlated changes in heterozygosity at an enzyme locus in the scallop (Pecten maximus L.). Anim. Blood Grps biochem. Gent. 9: 69-77

Wilkins, N. P., Mathers, N. F. (1974). Phenotypes of phosphoglucose isomerase in some bivalve molluscs. Comp. Biochem. Physiol. 48B: 599-611

Wright, S. (1965). The interpretation of population structure by F-statistics with special regard to systems of mating. Evolution 19: 395-420

This article was presented by Professor J. S. Gray; it was accepted for printing on October 14, 1988 